\title{
PELAKSANAAN STANDAR PELAYANAN KEFARMASIAN ASPEK VISITE DI RUMAH SAKIT X SESUAI PERATURAN PERUNDANGAN
}

\author{
I Made Sasmita Dwidhananta ${ }^{1}$, I Made Agus Gelgel Wirasuta ${ }^{1}$ \\ ${ }^{1}$ Program Studi Farmasi, Fakultas Matematika dan Ilmu Pengetahuan Alam, \\ Universitas Udayana \\ Jalan Kampus Unud-Jimbaran, Jimbaran-Bali, Indonesia 80364 \\ Telp/Fax: 0361-703837 \\ Email: d.sasmitadwidhananta30@gmail.com
}

\begin{abstract}
ABSTRAK
Pelaksanaan pelayanan kefarmasian pada pasien salah satunya berupa praktik apoteker ruang rawat melalui kegiatan visite. Penelitian ini bertujuan untuk mengetahui pelaksanaan standar pelayanan kefarmasian aspek visite di RS X sesuai peraturan perundangan yang berlaku. Penelitian ini bersifat deskriptif observasional. Teknik accidental sampling dengan indepth interview digunakan untuk memperoleh data observasi dan wawancara. Pelaksanaan standar pelayanan kefarmasian aspek visite di RS X telah sesuai dengan peraturan perundangan serta pedoman visite. Hasil evaluasi menunjukkan bahwa akurasi riwayat pengobatan pasien dilaksanakan dengan cukup, penilaian perencanaan pengobatan pasien saat ini dan pengkajian rejimen obat pasien dilakukan dengan baik, sedangkan pemberian konsultasi obat kepada pasien pulang (discharge patient) tergolong kurang. Faktor-faktor yang menjadi kendala dalam pelaksanaan visite di RS X adalah jumlah apoteker yang terbatas, waktu pelaksanaan yang terbatas, apoteker belum maksimal dalam memperoleh pelatihan mengenai farmasi klinik, serta dokter yang kurang merespon ketika diminta untuk menghentikan terapi ketika diberikan rekomendasi.
\end{abstract}

Kata kunci: Standar Pelayanan Kefarmasian, Visite, Apoteker

\begin{abstract}
One of the pharmacists practice in the implementation of pharmacy services for patients is through visite. This study is to determine the implementation of the visite of pharmaceutical services standards at X Hospital with applicable laws and regulations. This research is observational descriptive study. Accidental sampling technique and in-depth interview are used to obtain observation and interview data. The implementation of pharmacy service standards for visite aspects at X Hospital has been in accordance with the laws and regulations of visite. Evaluation results show that the accuracy of the patient's medical history is carried out sufficiently, the assessment of the current patient's treatment plan and assessment of the patient's drug regimen is carried out well, while the provision of drug consultations to discharge patients is classified as lacking. Factors that become obstacles in the implementation of the visite in Hospital $\mathrm{X}$ are the limited number of pharmacists, limited implementation time, pharmacists have not been maximized in obtaining training in clinical pharmacy, as well as doctors who do not respond when asked to stop therapy when given recommendations.
\end{abstract}

Keywords: Standards of Pharmaceutical Services, Visite, Pharmacist 


\section{PENDAHULUAN}

Apoteker memiliki banyak peran dan aplikasi profesional berkaitan dengan forensik. Farmasi forensik memungkinkan apoteker memberikan kontribusi penting dalam sistem peradilan. Apoteker dalam ilmu farmasi forensik terlibat dalam pekerjaan yang berkaitan dengan litigasi, urusan regulasi, atau sistem peradilan pidana, dengan menerapkan pengetahuan dalam ilmu farmasi dengan masalah hukum [2].

Apoteker di rumah sakit diharapkan memberikan pelayanan kefarmasian kepada pasien, yang memastikan bahwa pengobatan yang diberikan pada setiap individu pasien adalah pengobatan yang rasional. Pelayanan ini meliputi pelayanan farmasi klinik oleh apoteker di rumah sakit, yang ditujukan untuk memastikan bahwa pasien mendapatkan pengobatan yang rasional. Pelaksanaan pelayanan kefarmasian pada pasien salah satunya berupa praktik apoteker ruang rawat melalui kegiatan visite [6].

Visite apoteker di rumah sakit tercantum dalam Peraturan Menteri Kesehatan Republik Indonesia Nomor 72 Tahun 2016 tentang Standar Pelayanan Kefarmasian di Rumah Sakit. Visite merupakan kegiatan kunjungan ke pasien rawat inap yang dilakukan apoteker secara mandiri atau bersama tim tenaga kesehatan untuk mengamati kondisi klinis pasien secara langsung, dan mengkaji masalah terkait obat, memantau terapi obat dan reaksi obat yang tidak dikehendaki, meningkatkan terapi obat yang rasional, dan menyajikan informasi obat kepada dokter, pasien serta profesional kesehatan lainnya. Visite juga dapat dilakukan pada pasien yang sudah keluar Rumah Sakit baik atas permintaan pasien maupun sesuai dengan program Rumah Sakit yang biasa disebut dengan Pelayanan Kefarmasian di rumah (Home Pharmacy Care) [6].

Praktik visite yang dilakukan oleh apoteker bertujuan untuk: (1) meningkatkan pemahaman mengenai riwayat pengobatan pasien, perkembangan kondisi klinik, dan rencana terapi secara komprehensif; (2) memberikan informasi mengenai farmakologi, farmakokinetika, bentuk sediaan obat, rejimen dosis, dan aspek lain terkait terapi obat pada pasien; (3) memberikan rekomendasi sebelum keputusan klinik ditetapkan dalam hal pemilihan terapi, implementasi dan monitoring terapi; dan (4) memberikan rekomendasi penyelesaian masalah terkait penggunaan obat akibat keputusan klinik yang sudah ditetapkan sebelumnya [3].

Petunjuk teknis mengenai visite apoteker di rumah sakit diatur lebih lanjut oleh Kementerian Kesehatan Republik Indonesia tentang Pedoman Visite. Ruang lingkup visite yang dilakukan oleh apoteker berupa kunjungan apoteker ke pasien di ruang rawat, meliputi: (i) identifikasi masalah terkait penggunaan obat, (ii) rekomendasi penyelesaian/pencegahan masalah terkait penggunaan obat dan/atau pemberian informasi obat, (iii) 
pemantauan implementasi rekomendasi dan hasil terapi pasien [3].

Pelaksanaan visite mandiri dilakukan dengan tahapan, yaitu (1) memperkenalkan diri kepada pasien; (2) mendengarkan respon yang disampaikan oleh pasien dan identifikasi masalah; (3) memberikan rekomendasi berbasis bukti berkaitan dengan masalah terkait penggunaan obat; (4) melakukan pemantauan implementasi rekomendasi; dan (5) melakukan pemantauan efektivitas dan keamanan terkait penggunaan obat. Sedangkan untuk pelaksanaan visite tim dilakukan dengan tahapan,

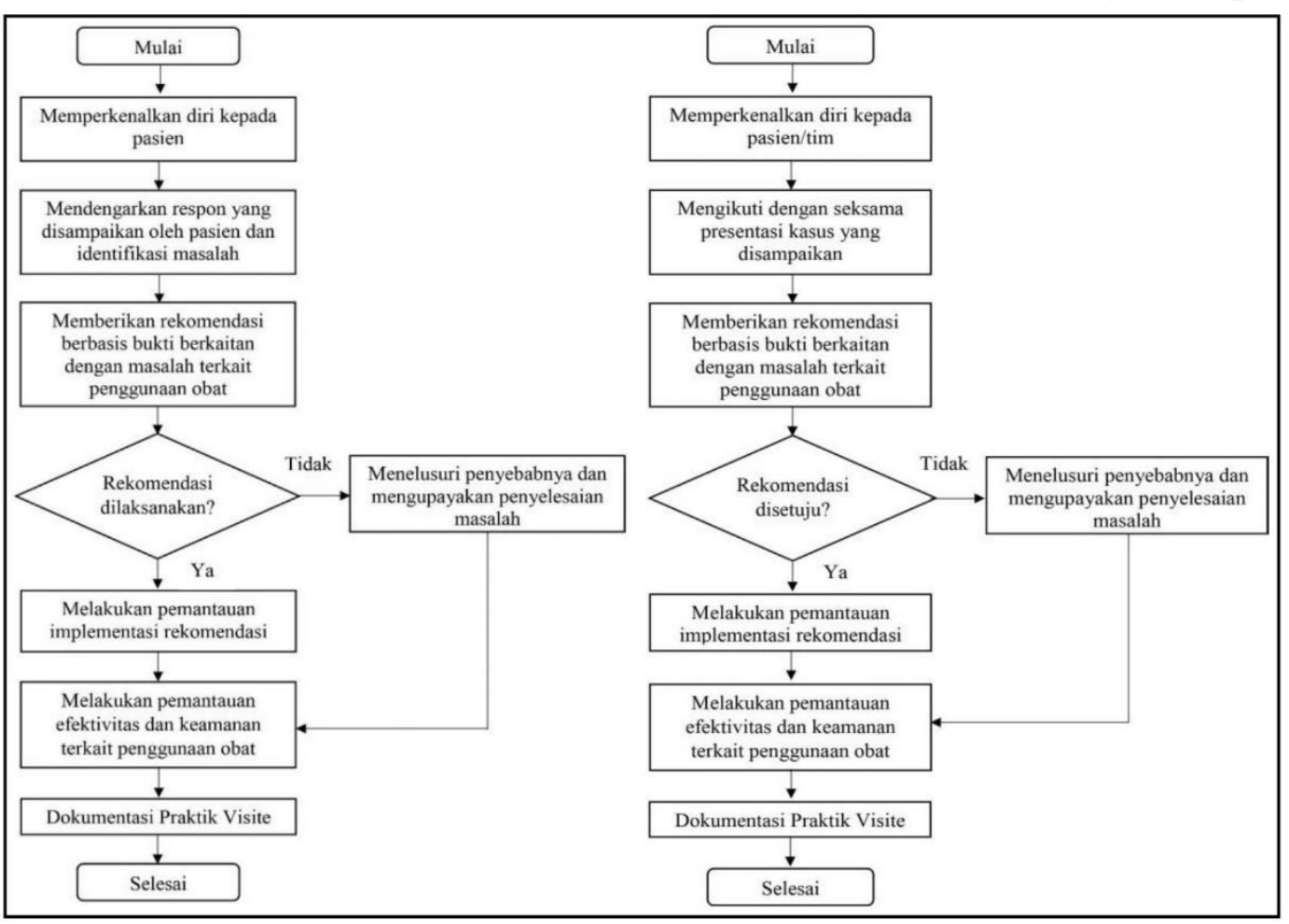

Gambar 1. Flowchart Visite Mandiri (Kiri) dan Visite Tim (Kanan) [3].

yaitu (1) memperkenalkan diri kepada pasien dan/atau tim; (2) mengikuti dengan seksama presentasi kasus yang disampaikan; (3) memberikan rekomendasi berbasis bukti berkaitan dengan masalah terkait penggunaan obat; (4) melakukan pemantauan

Apoteker perlu membekali diri dengan berbagai pengetahuan minimal sebelum memulai praktik visite di ruang rawat, diantaranya patofisiologi, terminologi medis, implementasi rekomendasi; dan (5) melakukan pemantauan efektivitas dan kemanan terkait penggunaan obat. Tahap terakhir yang harus dilakukan dari setiap pelaksanaan visite, baik secara mandiri atau tim adalah melakukan dokumentasi praktik visite [3].

farmakokinetika, farmakologi, farmakoterapi, farmakoekonomi, farmako- epidemiologi, pengobatan berbasis bukti. Selain itu diperlukan kemampuan interpretasi data 
laboratorium dan data penunjang diagnostik lain; berkomunikasi secara efektif dengan pasien, dan tenaga kesehatan lain [3].

Penelitian ini bertujuan untuk mengetahui pelaksanaan standar pelayanan kefarmasian aspek visite di RS $X$ sesuai peraturan perundangan yang berlaku oleh apoteker yang melaksanakan pekerjaan kefarmasian di rumah sakit. Penelitian ini bersifat deskriptif observasional untuk memberikan gambaran mengenai penelitian yang dilakukan dengan mengamati kondisi-kondisi yang terjadi melalui observasi langsung, yang didukung dengan pelaksanaan wawancara mendalam. Objek dalam penelitian ini dikhususkan di salah satu rumah sakit di Kabupaten Badung, Provinsi Bali.

\section{METODE PENELITIAN}

Penelitian ini bersifat deskriptif observasional. Penelitian ini dilakukan di salah satu rumah sakit di Kabupaten Badung, Provinsi Bali. Penelitian ini mengacu kepada Peraturan Menteri Kesehatan RI Nomor 72 Tahun 2016 tentang Standar Pelayanan Kefarmasian di Rumah Sakit dan Kementerian Kesehatan RI Tahun 2011 tentang Pedoman Visite.

Teknik indepth interview digunakan untuk memperoleh data wawancara, sedangkan teknik accidental sampling digunakan untuk memperoleh data observasi. Teknik indepth interview dilakukan dengan melakukan wawancara secara mendalam dengan 5 (lima) poin pertanyaan terkait pelaksanaan, teknik, jadwal, manfaat, dan kendala visite di rumah sakit. Data hasil wawancara disajikan dalam bentuk teks naratif. Teknik accidental sampling dilakukan dengan menggunakan 15 (lima belas) sampel untuk memperoleh data observasi terkait akurasi riwayat pengobatan pasien, penilaian perencanaan pengobatan pasien saat ini, pengkajian rejimen obat pasien, dan pemberian konsultasi obat kepada pasien pulang (discharge patient).. Data observasi yang telah diperoleh dilakukan scoring, kemudian data diinterpretasikan kedalam tiga kategori, yaitu : baik dengan rentang nilai $66,7 \%-100 \%$, cukup dengan rentang nilai $33,4 \%$ $66,6 \%$, dan kurang dengan rentang nilai $0 \%-33,3 \%$.

\section{HASIL dan PEMBAHASAN}

Penelitian ini dilaksanakan pada bulan Juli 2020 di RS X yang terletak di Kabupaten Badung. Pada penelitian dilakukan dengan wawancara dan observasi. Terdapat 5 poin pertanyaan dalam wawancara, sedangkan dalam observasi terdapat 4 indikator yang dievaluasi. Hasil evaluasi diuraikan pada Tabel 1.

Berdasarkan hasil wawancara, jenis visite yang dilakukan di RS X adalah visite mandiri dan visite tim. Visite di RS X dilakukan oleh 6 (enam) orang apoteker yang bertugas dalam pelaksanaan visite. Visite memberikan manfaat yang besar kepada pasien karena dapat meningkatkan outcome terapi dan pengeluaran biaya yang lebih rendah [4]. Outcome yang tidak sesuai dengan yang diharapkan dapat menyebabkan terjadinya kesalahan pengobatan di rumah sakit. 
Berdasarkan Laporan Insiden Keselamatan Pasien Rumah Sakit di Indonesia, kesalahan pengobatan berada pada peringkat pertama $(24,8 \%)$ dari 10 kejadian yang diumumkan [5]. Strategi yang dapat dilakukan untuk menghindari terjadinya kesalahan pengobatan salah satunya dengan adanya visite apoteker dalam ruang perawatan baik secara mandiri atau dengan tim. Visite apoteker yang dilakukan pada ruang perawatan intensif, 659 rekomendasi dari 1173 peresepan, dapat mengurangi tingkat kesalahan peresepan yang bermakna ( $p<0,001)$, menghindari reaksi obat yang tidak diinginkan, serta menunjukkan penghematan biaya sebesar 26-40 Euro [4].

Apoteker yang bertugas melaksanakan visite di RS X akan melihat prioritas terlebih dahulu terhadap pasien yang akan dilakukan visite. Adapun prioritas yang ditinjau meliputi, pasien baru, pasien rawat bersama, pasien yang sedang mendapatkan perawatan intensif, pasien dengan hasil pemeriksaan laboratorium mencapai titik kritis, pasien yang menerima obat lebih dari 5 / polifarmasi, serta pasien yang memperoleh obat dengan indeks terapi yang sempit dan memiliki efek samping yang berbahaya. Kesalahan dalam pengobatan di ruang perawatan intensif memiliki potensi fatal dibandingkan dalam ruang rawat inap. Tingkat keparahan penyakit, komplikasi, dan polifarmasi merupakan hal yang penting untuk diperhatikan [5].

Apoteker akan melakukan pengumpulan informasi penggunaan obat. Kegiatan tersebut dilakukan dengan melihat rekam medik pasien maupun dengan melakukan wawancara secara spesifik dengan pasien/keluarganya. Informasi yang diperoleh dapat berupa data pasien, keluhan, riwayat penyakit, riwayat penggunaan obat, riwayat alergi, hingga data hasil pemeriksaaan laboratorium. Kemudian, apoteker yang bertugas akan melakukan pengkajian masalah terhadap obat yang digunakan yang terkait efek samping obat, biaya, serta efektivitas terapi. Hal tersebut penting untuk dilakukan untuk menghindari terjadinya penggunaan obat yang salah yang merupakan faktor utama penyebab kerugian pasien [5].

Tahapan yang dilakukan oleh apoteker di RS X dalam melaksanakan visite mandiri, dimulai dengan memperkenalkan diri terlebih dahulu. Hal ini penting untuk meningkatkan kepercayaan pasien terhadap apoteker sehingga dapat diperoleh informasi yang sesuai keadaan pasien. Kemudian apoteker akan mengkaji respon pasien dan melakukan identifikasi masalah. Hal tersebut dilakukan untuk memastikan kesesuaian pengobatan yang diberikan. Kemudian apoteker akan memberikan rekomendasi untuk meningkatkan kepatuhan penggunaan obat. Rekomendasi yang diberikan meliputi edukasi dan pendampingan dalam tata cara pemakaian obat. Selanjutnya apoteker akan melaksanakan pemantauan hasil rekomendasi dengan mengacu pada masalah yang ada. Terakhir, apoteker akan memantau efektivitas dan keamanan terkait penggunaan obat yang 
berhubungan dengan efektivitas terapi serta efek samping obat.

Tahapan yang dilakukan oleh apoteker di RS X dalam melaksanakan visite tim, dimulai dengan memperkenalkan diri terlebih dahulu kepada pasien dan/ tim. Hal ini penting untuk meningkatkan kepercayaan pasien dan tim terhadap apoteker sehingga dapat diperoleh informasi yang sesuai keadaan pasien. Kemudian apoteker akan mengikuti dengan saksama presentasi kasus yang disampaikan dalam tim. Kemudian apoteker akan memberikan rekomendasi berbasis bukti yang berkaitan dengan masalah terkait penggunaan obat. Kemudian apoteker akan melakukan pemantauan implementasi rekomendasi dengan mengacu pada masalah yang ada. Terakhir, apoteker akan memantau efektivitas dan keamanan terkait penggunaan obat yang berhubungan dengan efektivitas terapi serta efek samping obat. Tahapan yang dilakukan oleh apoteker yang bertugas dalam pelaksanaan visite baik secara mandiri maupun bersama tim di RS $\mathrm{X}$ telah sesuai dengan pedoman visite [3].

Dalam melaksanakan kegiatan visite mandiri dan tim, apoteker melaksanakan pendokumentasian yang dicatat pada lembar dokumentasi visite dan lembar pengkajian obat. Pencatatan yang dilakukan mengenai penggunaan obat, rekomendasi, serta hasil terapi. Dokumentasi yang dilakukan dikelola dengan menjaga kerahasiannya. Tujuan dari dilaksanakannya pendokumentasian kegiatan visite adalah untuk menjamin akuntabilitas dan kredibilitas, sebagai bahan evaluasi dan perbaikan mutu kegiatan, serta sebagai bahan pendidikan dan penelitian kegiatan [3].

Apoteker yang bertugas memberikan pelayanan visite di RS $\mathrm{X}$ memiliki jadwal tugas setiap hari yang dilaksanakan mulai pukul 09.00-13.00 WITA. Visite mandiri dan tim dilaksanakan tergantung pada pelaksanaan di masing-masing ruangan. Jadwal diruangan dibagi menjadi apoteker yang melaksanakan visite di ruang intensif pada khususnya, serta beberapa ruangan lainnya. Sebanyak 6 (enam) orang apoteker yang bertugas dalam visite dituntun untuk hadir selama jam kerja visite serta bertanggung jawab atas pelayananan visite yang diberikan di masing-masing ruangan. Waktu dalam pelaksanaan visite tergantung pada tingkat pemahaman pasien dan informasi yang diberikan.

Manfaat yang diperoleh oleh apoteker yang melaksanakan visite, yaitu (1) memperoleh pendidikan, pelatihan, dan penelitian dalam memenuhi kompetensi standar profesi; (2) secara aktif terlibat dalam penelitian penggunaan obat (drug use study); (3) dapat meningkatkan kompetensi tentang sediaan farmasi dan alat kesehatan; (4) melatih soft skill dengan secara aktif bekerjasama antar profesi kesehatan lainnya di rumah sakit; dan (5) dapat menyelesaikan masalah terkait penggunaan obat, serta efektivitas obat dapat dipantau [3]. Manfaat yang diperoleh oleh pasien, yaitu (1) memperoleh obat 
yang sesuai dengan rejimen pengobatan, meliputi indikasi, dosis, waktu, bentuk sediaan, frekuensi, dan rute obat; (2) memperoleh terapi obat yang efektif yang memiliki risiko minimal, meliputi efek samping, biaya, dan medication errors; dan (3) memperoleh informasi, konseling, dan saran dalam pelaksanaan terapi pengobatan. Keuntungan yang diperoleh oleh RS X, diantaranya (1) peningkatan mutu manajemen RS X dalam mencapai aspek visite yang sesuai dengan Standar Pelayanan Kefarmasian di Rumah Sakit; (2) meningkatnya keamanan dari medication errors; (3) mengoptimalkan efektifitas biaya (cost effectiveness) dalam terapi pengobatan; dan (4) meningkatnya kerjasama tim yang saling menghargai kode etik masingmasing profesi [9].

Faktor-faktor yang menjadi kendala dalam pelaksanaan visite di RS X diantaranya adalah terkait jumlah apoteker yang terbatas, pembagian waktu dalam pelaksanaan visite yang masih terbatas, apoteker belum maksimal dalam memperoleh pelatihan mengenai farmasi klinik, serta dokter yang kurang merespon ketika diminta untuk menghentikan terapi ketika diberikan rekomendasi.

Evaluasi dilakukan untuk menjamin kualitas pelayanan aspek visite berdasarkan indikator yang telah ditetapkan. Evaluasi dilakukan pada proses input dan output. Teknik accidental sampling sebanyak 15 sampel digunakan untuk memperoleh data observasi. Data observasi yang telah diperoleh kemudian dilakukan scoring dengan tiga kategori, yaitu baik, cukup, dan kurang. Pada Tabel 1. diketahui bahwa persentase pasien yang telah dilakukan wawancara oleh apoteker mengenai riwayat pengobatan setelah pasien masuk rumah sakit dalam 24 jam dilakukan dengan persentase $60 \%$. Data tersebut tergolong dalam kategori cukup. Aktivitas pengumpulan informasi mengenai kondisi pasien dan riwayat pengobatan pasien telah cukup terlaksana. Dalam pelayanan farmasi klinis, apoteker memiliki peran menelusuri pengobatan pasien ketika pasien masuk rumah sakit [7].

Penilaian terkait perencanaan pengobatan pasien saat ini mengkaji mengenai jumlah penilaian apoteker terhadap perencanaan pengobatan pasien saat sekarang dibagi total hari rawat pasien, dimana persentase dilakukan yang diperoleh sebesar $80 \%$, sehingga tergolong dalam kategori baik. Penilaian perencanaan pengobatan perlu dilakukan untuk menyesuaikan intervensi pengobatan yang dilakukan, serta mencegah terjadinya reaksi obat yang tidak diinginkan berdasarkan studi ilmiah [1]. 
Tabel 1. Evaluasi Kualitas Pelayanan Aspek Visite di RS X

\begin{tabular}{|c|c|c|c|c|c|}
\hline \multirow{2}{*}{ No. } & \multirow{2}{*}{ Evaluasi } & \multicolumn{2}{|c|}{ Jumlah } & \multicolumn{2}{|c|}{ Persentase } \\
\hline & & $\mathrm{Ya}$ & Tidak & $\mathrm{Ya}$ & Tidak \\
\hline 1. & $\begin{array}{l}\text { Akurasi riwayat } \\
\text { pengobatan pasien }\end{array}$ & 9 & 6 & $60 \%$ & $40 \%$ \\
\hline 2. & $\begin{array}{l}\text { Penilaian perencanaan } \\
\text { pengobatan pasien saat } \\
\text { ini }\end{array}$ & 12 & 15 & $80 \%$ & $20 \%$ \\
\hline 3. & $\begin{array}{l}\text { Pengkajian rejimen obat } \\
\text { pasien }\end{array}$ & 14 & 1 & $93,3 \%$ & $6,7 \%$ \\
\hline 4. & $\begin{array}{l}\text { Pemberian konsultasi } \\
\text { obat kepada pasien } \\
\text { pulang } \quad \text { (discharge } \\
\text { patient) }\end{array}$ & 2 & 13 & $13,3 \%$ & $86,7 \%$ \\
\hline
\end{tabular}

Pengkajian rejimen obat pasien oleh apoteker dengan persentase dilakukan sebesar 93,3\%, dimana tergolong dalam kategori baik. Pengkajian pengobatan yang dilakukan dengan cara seperti skrining resep, order oleh dokter, dan rekonsiliasi pengobatan oleh apoteker merupakan hal penting untuk dilakukan agar tercipta hasil pengobatan pasien yang baik serta aman [8]. Apoteker memiliki peran yang sangat penting dalam membantu menurunkan kesalahan pengobatan dan peresepan dalam pelaksanaan terapi [4]. Dengan adanya pendampingan oleh apoteker, kesalahan dalam peresepan terbukti secara efektif dapat dicegah, sehingga penerapannya dapat lebih diperluas untuk dilakukan di ruang rawat lainnya [9].

Pemberian konsultasi obat kepada pasien pulang (discharge patient) yang dinilai terhadap pasien yang memperoleh konsultasi mengenai obat oleh apoteker ketika pasien pulang dari rumah sakit. Persentase dilaksanakan yang diperoleh adalah 13,3\%, sehingga tergolong dalam kategori kurang. Peningkatan pendampingan apoteker kepada pasien sebagai penerapan pelayanan farmasi klinik sangat diperlukan. Sistem manajemen rumah sakit dan komunikasi interpersonal antar profesi kesehatan yang baik akan meningkatkan kegiatan pendampingan apoteker kepada pasien [8].

Berdasarkan hasil evaluasi, menunjukkan bahwa akurasi riwayat pengobatan pasien telah dilaksanakan dengan cukup, penilaian perencanaan pengobatan pasien saat ini dan pengkajian rejimen obat pasien oleh apoteker yang melaksanakan visite telah dilakukan dengan baik, sedangkan pemberian konsultasi obat kepada pasien pulang (discharge patient) tergolong kurang, sehingga 
diperlukan perbaikan yang dapat meningkatkan kualitas pelayanan. Kegiatan pendampingan oleh apoteker harus selalu dilakukan untuk perbaikan dan peningkatan mutu pelayanan aspek visite sebagai implementasi dalam pelaksanaan pelayanan farmasi klinik di rumah sakit [9].

Berdasarkan kesesuaian dengan SOP (Standar Operasional Prosedur) visite, dapat disimpulkan bahwa pelaksanaan visite mandiri dan tim di RS X telah sesuai dengan pedoman visite yang dikeluarkan oleh Kementerian Kesehatan Republik Indonesia, dimana tahapan yang dilakukan dalam pelaksanaan visite mandiri oleh apoteker di RS X, meliputi (1) memperkenalkan diri kepada pasien; (2) mendengarkan respon yang disampaikan oleh pasien dan identifikasi masalah; (3) memberikan rekomendasi berbasis bukti berkaitan dengan masalah terkait penggunaan obat; (4) melakukan pemantauan implementasi rekomendasi; (5) melakukan pemantauan efektivitas dan keamanan terkait penggunaan obat; dan (6) melaksanakan dokumentasi praktik visite. Tahapan pelaksanaan visite tim oleh apoteker di RS X, meliputi memperkenalkan diri kepada pasien dan/tim; (2) mengikuti dengan seksama presentasi kasus yang disampaikan; (3) memberikan rekomendasi berbasis bukti berkaitan dengan masalah terkait penggunaan obat; (4) melakukan pemantauan implementasi rekomendasi; (5) melakukan pemantauan efektivitas dan keamanan terkait penggunaan obat; dan (6) melaksanakan dokumentasi praktik visite.

\section{KESIMPULAN}

Pelaksanaan standar pelayanan kefarmasian aspek visite baik secara mandiri maupun tim di RS X telah sesuai dengan peraturan perundangan serta pedoman visite. Hasil evaluasi menunjukkan bahwa akurasi riwayat pengobatan pasien telah dilaksanakan dengan cukup, penilaian perencanaan pengobatan pasien saat ini dan pengkajian rejimen obat pasien oleh apoteker yang melaksanakan visite telah dilakukan dengan baik, sedangkan pemberian konsultasi obat kepada pasien pulang (discharge patient) masih tergolong kurang.

\section{UCAPAN TERIMA KASIH}

Penulis menyampaikan ucapan terima kasih kepada Program Studi Farmasi, Fakultas MIPA Universitas Udayana, serta pihak RS X di Kabupaten Badung atas kesempatan, bantuan, dan dukungan yang diberikan dalam penyelesaian penelitian ini.

\section{DAFTAR PUSTAKA}

[1] Abdulkadir W.S. Model Kolaborasi Dokter, Apoteker dan Direktur terhadap Peningkatan Efektivitas Teamwork di Rumah Sakit. Jurnal Farmasi Klinik. 2017; 6(3): 210-219.

[2] Anderson P.D. Introduction. Journal of Pharmacy Practice. 2012; 25(1): 5-6.

[3] Kemenkes RI. Pedoman Visite. Jakarta: Kementerian 
Kesehatan Republik Indonesia; 2011.

[4] Klopotowska J.E, Kuiper R., Van Kan H.J., Pont A.C., Dijkgraaf M.G., Lie-Ahuen L., et al. On-Ward Participation of A Hospital Pharmacist in A Dutch Intensive Care Unit Reduces Prescribing Errors and Related Patient Harm: An Intervention Study. Critical Care. 2010; 14(5): 1-11.

[5] Latif A., Rawat N., Pustavoitau A., Pronovost P.J., and Julius C. National Study on the Distribution, Causes and Consequences of Voluntarily Reported Medication Errors Between the ICU and Non-ICU Settings. Critical Care Medicine. 2013; 41(2): 389398.

[6] Menkes RI. Peraturan Menteri Kesehatan Republik Indonesia No.72 Tahun 2016 tentang Standar Pelayanan Kefarmasian di Rumah Sakit. Jakarta: Menteri Kesehatan Republik Indonesia; 2016.

[7] Raimbault-Chupin M., Spiesser-Robelet L., Guir V., Annweiler C., Beauchet O., Clerc M.A., and Moal F. Drug Related Problems and Pharmacist Interventions in A Geriatric Unit Employing Electronic Prescribing. International Journal of Clinical Pharmacy. 2013; 35(5): 847-853.

[8] Ratnadevi T., dan Putriana N.A. Pengaruh Pelayanan Farmasi Klinis Di Rumah Sakit Oleh Apoteker Pada
Kejadian Permasalahan Terkait Obat. Jurnal Farmasi dan Kesehatan. 2018; 8(1): 104-118.

[9] Turnodihardjo M.A., Hakim L., dan Kartikawatiningsih D. Pengaruh Pendampingan Apoteker Saat Visite Dokter terhadap Kesalahan Peresepan di Ruang Perawatan Intensif. Jurnal Farmasi Klinik Indonesia. 2016; 5(3): 160-16 